\title{
PHONOLOGICAL REFLEXES OF EMPHASIS IN KWA LANGUAGES OF CÔTE D'IVOIRE
}

\author{
William R. Leben and Firmin Ahoua
}

\section{Introduction}

This paper examines the phonological characteristics of expressions conveying emphasis, insistence, and contrast in some Kwa languages of Côte d'Ivoire. (For the classification of Kwa languages, see Stewart $(1989,2001,2002))$. Our particular interest is to reveal how such phenomena are realized in tonal languages, and we thought it worthwhile to study more than one language yet to confine the study to a closely related group. In this group a variety of phonological strategies are used to mark emphasis, including prosodic devices that have not been widely reported in the literature for Niger-Congo languages, and that may or may not differ from other language groups

For our subject we have avoided the more restrictive term focus in favor of the more general term emphasis due to the latter's suggestive but open-ended phonological and semantic implications. Some of the constructions examined here correspond to focus as generally used in the literature, notably in Bearth's (1999) survey of focus in African languages. But other cases do not involve focus in the strict sense. For example, some of them are appropriately glossed by adding an expression like "really" or "please" to the word or phrase emphasized. What is interesting is that while the constructions described are quite heterogeneous from a semantic standpoint, they involve many of the same phonological devices.

In a nutshell, our goal is to capture the various phonological means for expressing emphasis in the Kwa languages of Côte d'Ivoire. It is normal to encounter special emphatic particles in these languages, as elsewhere, but there are also specific tonal and intonational effects which apply in the presence or absence of such particles. Also present, and less often described, are cases in 
which emphasis interrupts the regular phonological patterns. We capture this disruptive effect with an emphasis boundary which creates a new phonological phrase for the emphasized constituent. Cases like these appear to have an analog in other languages, notably Pierrehumbert and Beckman's (1988) analysis of Japanese, where emphasis leads to the formation of new accentual phrases.

The rest of the paper is divided into six sections. Section 1 examines segmental processes and considers independent evidence from tonal processes. Section 2 discusses negation and final particles as contexts for emphasis marking. Section 3 deals with ideophones with emphatic meanings. Section 4 investigates types of emphasis marking by nominalization of the verb. Section 5 illustrates some types of prosodic marking of emphasis by register raising. Section 6 summarizes the results of the paper.

The language for which we have the most detail is Standard Baule, which is the most widely spoken of the group and one spoken natively by one of the authors. We add data from a second Baule dialect, Kode, and from neighboring Kwa languages Adioukrou, Eotile, and Akye. Our analysis is based on data from Leben and Ahoua (2002), the first volume of a comparative study of the phonology of Kwa languages of Côte d'Ivoire currently in progress.

\section{Domains of Emphasis: Tests with Elision and Tones}

\subsection{Blocking of Elision}

Baule has a number of multi-word constructions that function phonologically as single prosodic words: proper names, compound nouns, noun-adjective constructions. See Leben and Ahoua (1997) for the analysis. Emphasis on one of the elements of a multi-word prosodic word unit breaks the complex up into two constituents, a non-emphasized portion and an emphasized one. The evidence in 1.3 below will suggest that the emphasized constituent becomes a new phonological phrase.

For example, the first and last names in a proper name ordinarily comprise a single prosodic word (see Leben and Ahoua 1997). One sign of this is the applicability a rule of elision deleting one of two adjacent vowels. This rule applies only within prosodic words, as illustrated in (1a) below, and never applies across different prosodic words. In example (1b), which emphasizes the second name àmàní, elision is blocked. 
(1)
Underlying form
Surface form
a. / djáá àmàní /
[ jámàní ]
'Djaha Amani'
b. / djáá | àmàní /
[ jáá àmà̀ní ]
'Djaha Amani'

The same effect is found in examples (2), (3), and (4) below. In all cases, emphasis on the final element breaks a constituent into two parts, with the emphasized element heading a new prosodic constituent. We represent this change by placing an emphasis boundary $(\mid)$ before the emphasized word.

Example (2) shows a title of address followed by a person's name. These two elements form a single prosodic word in (2a). Emphasis on the second element again breaks this constituent up into two parts in (2b).

(2)
a. / ǹdjá àmàní / [ ǹjámàní ]
'Mr. Amani'
b. / ǹdjá | àmàní /
[ ǹjá ámàní ]
'Mr. Amani'

Examples (3a,b) are names with titles, like (2a). In (3c) the names after the title are used contrastively. As before, an emphasis boundary is placed before the contrastive elements, and so once again elision is blocked. Contrastive emphasis on both elements of $(3 \mathrm{c})$ leads to blocking of elision in both cases, as predicted.
(3)
a. / mó ámlą́ /
[ mámlá ]
'Mrs. Amlan'
b. / mó àmàní /
[ mámàní ]
'Mrs. Amani'
c. / mó | ámlǻ nǻ /
[ mó ámla्a nã ]
'it is Mrs. Amlan
/ mó | àmàní j̀ /
[ mó àmàníi j̀ ]
not Mrs. Amani'

\subsection{Tonal Blocking: Interruption of Upsweep}

Leben and Ahoua (1997) discuss a gradual rise in F0 across a sequence of High tones within the same phonological word. This gradual rise is referred to as upsweep (Ahoua 1996, Dafydd Gibbon personal communication).

As seen in 1.1, emphasis on the final element of a phrase causes an emphasis boundary to be inserted before it, blocking elision. Independent motivation for this emphasis boundary is its intonational effects. Compare (4a), which lacks emphasis, to (4b), in which the second element is emphasized:
(4)
a. / ákíssí bólí /
[ ákísí bólí ]
'Akissi Boli' (proper name)
b. / ákíssí|bólí / [ ákísí bőlî́] 'Akissi Boli' 
Example (4a) has the melody of the unmarked neutral utterance, with gradual upsweep on successive High tones. The version in (4b) shows emphatic marking of the proper name Boli. In this case, the emphasis boundary interrupts upsweep, and tonal register of the whole word is raised. We refer to a High tone in raised register as Super-High and notate it with a double acute. The Super-High sequence bólí is itself subject to upsweep, so that the second Super-High syllable is even higher than the first, but the point of the example is that the emphasis boundary interrupts the normal upsweep pattern.

Now suppose we emphasize the entire expression (4a)? In this case, an emphasis boundary will not be inserted within the expression. This in turn predicts that the expression will remain a single phonological word, with a single tonal upsweep pattern. As with the preceding examples, the register will be raised for the emphasized constituent, in this case the entire expression, as shown in (5).

$$
\text { [ á kîsí bólî́ ] 'Akissi Boli’ (entire proper name emphasized) }
$$

We have also checked for what would happen when only the first word in this expression was emphasized, but consultants consistently rejected that pattern. In fact, our work suggests a general restriction on the placement of emphasis: only phrase-final elements may be emphasized.

\subsection{Interruption of Low Tone Spreading.}

Baule has a rule of Low Tone Spreading, which applies not only within phonological words but also across phonological words within phonological phrases:

(6) LOW TONE SPREADING: $\mathrm{H} \rightarrow \mathrm{L} / \mathrm{L} \_\mathrm{H}$

The symbols $\mathrm{H}$ and $\mathrm{L}$ here refer to strings of one or more High and Low tones, respectively. Examples (7a) and (8b) show that the rule would need to be complicated if these symbols referred only to individual tone-bearing units.

Rule (6) applies within a phonological phrase but not across phrases. In (7) and (8), nà̃ní means 'cow' and nớnó means 'milk.' The unemphasized expressions (7a) and (8a) sound identical. The only difference between them is a structural one. The compound (7a) is a single prosodic word whereas (8a), a possessive phrase, is a phonological phrase consisting of two prosodic words. Compare the (a) cases to the (b) ones, which add emphasis on the final noun. 
(7) a. /nã̀ní nỡnơ / [ nà̀nì nò̀nơ ] 'cow milk'

b. /nà̀ní | nỡnó / [ nà̀ní nỡnō ] 'cow milk'

(8) a. /nà̀ní nớnó / [ nã્̀ì̀ nờnó ] 'cow's milk'

b. /nà̀ní | nớnơ / [ nã्aí nỡnơ ] 'cow's milk'

In the (b) cases, the emphasized second word causes the phonological domain of Low Tone Spreading to be interrupted. Thus, an emphasis boundary in (7b) and (8b) must create not just a new prosodic word but a whole new phonological phrase. The same, of course, must apply to examples (1) through (6). Thus, the conclusion from this section is that an emphasis boundary is placed before an emphasized element, creating a new phonological phrase for that element.

\section{Constructions and Particles that Signal Emphasis}

In this section we describe utterances containing an emphatic particle. We begin with negative constructions. The negative marker má behaves as if it is inherently emphatic because it conditions a raising in tone that is characteristic of emphatic expressions.

\subsection{Negation and Emphasis}

To understand what happens in negative utterances, it is first useful to see how positive assertions are expressed, as in (9).

$$
\begin{aligned}
& \text { ò kó 'he/she goes' } \\
& \text { ò bá 'he/she comes' } \\
& \text { ò dí 'he/she eats' }
\end{aligned}
$$

Such assertions are negated by adding má to the main verb and raising the tone of the verb to a Super-High tone:

$\begin{array}{ll}\text { (10) ò k’ mãa } & \text { 'he/she doesn't go' } \\ \text { ò bă mãa } & \text { 'he/she doesn't come' } \\ \text { ò dí mãa } & \text { 'he/she doesn't eat' }\end{array}$

Next consider the case where the scope of negation is restricted to a single constituent of a sentence. An emphasized noun $\mathrm{N}$ can be negated to express 'it isn't N' by prefixing ná to the noun, raising the noun's first tone to Super-High, 
and raising any following High to Super-High as well. As we see in (11) and (12), this raising neutralizes the contrast between the High and Low of the first syllable of bólí and nà̀ní:

\section{(11) bólí 'goat'}

ná bôlí j̀ 'lit. Neg. -goat- Final particle' 'it isn't a goat'

(12) nàníi 'cow'

ná na्anî̃ j̀ 'lit. Neg. -cow- Final particle' 'it isn’t a cow'

\subsection{The emphatic particles è, dé, and ó}

There are at least ten particles in Baule that serve to mark emphasis on a preceding or a following word, each with its own meaning. Particles with similar function are studied in detail by Ameka (1992) in another Kwa group, Akan, where they have a similar phonetic form. In Baule the suffixed particles è, $d \tilde{\varepsilon}$, ó raise the tone of the syllable immediately preceding them to Super-High. They may also raise the whole prosodic word, as noted for è by Creissels and Kouadio (1979) as a "particule d'insistance." Examples of each are given in the subsections below.

2.2.1. The emphatic particle è. The particle è is principally used after a verb or a noun. In (13) we can interpret it as 'why don't you?' or 'please.'

(13) a. mé 'swallow (imperative)'

b. m气̃ è 'swallow, please'

c. dí 'eat (imperative)'

d. dí è 'eat, please'

e. nó 'drink (imperative)'

f. nơ è 'drink, please'

Figure 1 compares typical measurements for $(13 \mathrm{a}, \mathrm{b})$ as uttered by a male speaker. The F0 of (13a) rises to a maximum around $184 \mathrm{~Hz}$. Adding a Low-toned $e$ in (13b) raises this maximum to around $222 \mathrm{~Hz}$ in (13a). As with the cases seen earlier, (13a) occurs in normal register while (13b) occurs in raised register. By contrast, a High tone before Low in a non-emphatic environment is pronounced in a normal register (Ahoua 1996, citing Quaireau 1981).

Surprisingly, the Super-High imposed by the emphatic particle è extends leftward to the beginning of the emphasized expression, including even phonological Low tones in its path. As a result, the contrast between Low and High tone is neutralized. In figure 2, the pitch curves on the right are nearly identical for /gbăflę nớnó è/ 'young man's milk' and /bólí nỡnớ è/ 'goat's milk.' 


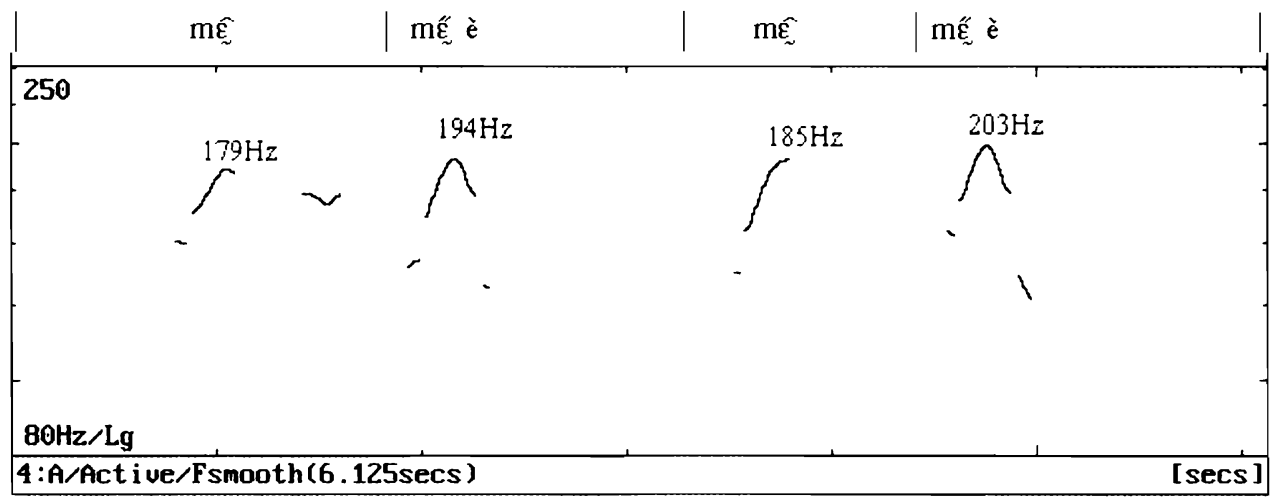

Figure 1: Monosyllabic utterance with and without emphatic è.
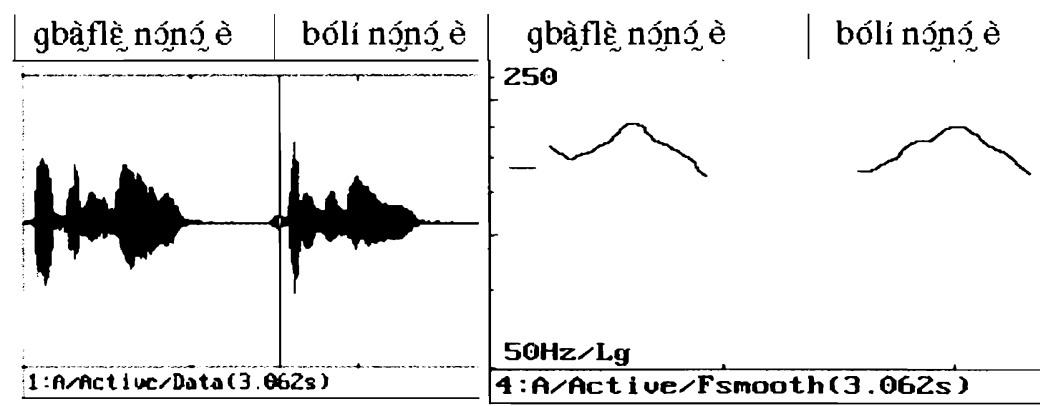

bólí nỡnọ è

Figure 2: Two polysyllabic utterances tonally neutralized before emphatic è.

The neutralization appears to extend over arbitrarily long sequences of High and Low tones. Thus, when / kòfí nàníi / 'Koffi's cow' appears before particle è both the initial Low of kòfí and the initial Low of nàníi are pronounced no differently from the High tones of bólí nơngo è. That is, before è the tones of the entire expression become Super-High.

2.2.2. The emphatic particle ó. The particle ó can generally be paraphrased by 'really' or 'indeed.' It can appear after any syntactic category but tends to appear especially after verbs. Notice that it raises the rightmost syllable of the immediately preceding word to Super-High, with no other tonal changes. 
(14) ò tì bólí ô

3 sg -be-goat-Part

ò sì yué srô ô

3sg -can-song-sing -Part

ว̀ nö ô

3sg -drink- Part.

ò đí ô

3sg -eat-Part.

ว̀ nà̀tì nẽ्̀d

3sg -walk-fast-Part. 'he/she is a real goat!' (an insult, he/she's silly)'

'he/she can sing songs very well!'

'he/she really drinks!' (he/she is a drinker)'

'he/she is greedy'

'he/she can really walk very fast'

This particle neutralizes the distinction between Low and High tone, as shown with the words mlà 'Wednesday' and mlà 'sponge' in (15).

(15) ké à kòlé, fà mlá

if -2sg -go-there-, take -sponge

ké à kòlé, fà mlă ó

if -2sg -go-there-, take -sponge-Part.

ké à kòlé, fà mlà̀

if -2sg -go-there-, take -Wednesday

ké à kòlé, fà mlä ó

if -2sg -go-there-, take -Wednesday-

Part. 'as you go, choose a sponge'

'as you go, choose just a sponge'

'as you go, choose Wednesday'

'as you go, choose Wednesday only, nothing else!'

2.2.3. The emphatic particle dé. In Baule, the particle dé serves to mean 'actually.' In contrast to the particle ó, which raises only the preceding syllable to Super-High, before $d \tilde{\varepsilon}$ both the verb and the following negative particle má⿱ raise to Super-High. This is as expected, since as noted above in (10) the negative particle má⿱ raises the verb to High.

(16) j̀ kó må dé

'he/she doesn't (actually) go!'

3 sg -go-Neg-Part.

j̀ bă mã dế 'he/she doesn't (actually) come!'

3sg -come-Neg-Part.

ว̀ dí mä dé

3sg -eat-Neg-Part. 'he/she doesn't (actually) eat!'

Particles in another Baule dialect, Kode, and in other very closely related Kwa languages serve similar functions. A few examples are given below. We are not 
sufficiently familiar with the tonal and intonational systems of these languages to know whether the tonal register is raised as in the Baule cases we have described above.

Kode:

$\begin{array}{llll}\bar{n} \text { bă } & \text { 'I'm coming' } & \bar{n} \text { bǎ } \bar{o} & \text { 'I'm coming, already!' } \\ \bar{\varepsilon} \text { t1 dà } & \text { 'it's big' } & \bar{\varepsilon} \text { ti dà o } & \text { 'is it ever big!' } \\ \text { flè̀ jìsá } & \text { 'call N'guessan' } & \text { fl } \bar{\varepsilon} \text { jìsá ké ke' } & \text { 'please call N'guessan' } \\ \text { kǒ } & \text { 'leave' } & \text { kǒ èè } & \text { 'leave, already!' }\end{array}$

Adioukrou:

(18) lòtú 'he/she is strong' lòtú gbé 'he/she is really strong!' òw 'come!' òw j̀ 'please come'

òw 'come!' òw ó 'come, already!'

Akye:

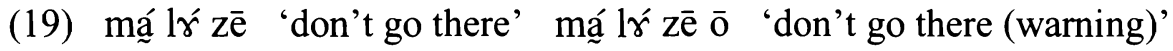
má l'r zē à 'please, don't go'

àpō 'Apo' (name) àpō $\overline{\mathrm{e}}$ 'Apo! (calling with insistence)'

In Eotile, the emphatic final particle is an unspecified vowel that merely copies the tone and the vowel quality of the last vowel of the adjectives or the emphasized word:

\section{Eotile:}

(20) wó gbà 'he/she's good' wó gbà à 'he/she is good' 3 sg -good

wó pl(ò) àmí 'he/she's ugly' wó pl(ò) àmì İ 'he/she's ugly' 3sg- ugly

In Aboure, the emphatic marking is expressed by kúwé bá or only the first item, or optionally with the particle $\sigma$ : 
Aboure:
(21) àmừ
(that's ) a dog'
àmứ kúwé
'(that's) actually a dog'
àmứ kúwé bá
'(that's) actually a dog'
àmứ ó
'(that's) actually a dog'
kòfí
'(that's) Koffi'
kòfí kúwé
'(that's ) actually Koffi'
kòfí kúwé bá '(that's ) actually Koffi '

To summarize, in Baule register raising is associated with the emphatic particle, though each particle has its own pattern of raising. è causes the entire emphasized expression to be raised to Super-High, regardless of whether the underlying tones are High or Low. ó raises only the immediately preceding syllable. dé raises an unbroken string of preceding High tones to Super-High but does not affect Low tones. While we have data on particles for the Kode dialect of Baule and for a number of other languages of the same group, we are unable to judge whether these particles are associated with register raising in these languages.

\section{Ideophones}

The ideophone létété is used to mean 'without stopping' or 'so much.' It serves to express the degree of intensity of an action. It is generally added after verbs. The syllable té can be reduplicated indefinitely. létété is pronounced with a SuperHigh tone, but without raising the register for the following or preceding words. Below are two examples.

(22) j̀ đi Iı bòlí létététété bòsú

3 sg - eat - Past - goat - Ideophone (long) - exceed

'he/she ate goat until he/she couldn't any more'

ò yrà létététététété nà wà kò trà̀sé

$3 \mathrm{sg}$ - stand - Ideophone - then - 3sg- past- go- sit- down

'he/she stood very long before he/she went to sit down'

Several other Baule ideophones behave similarly: làláá, cyekéé, màn, wù, ó. 


\section{Emphasis on Verbs}

To emphasize a verb, the main verb with its complements is repeated at the very beginning of the sentence. The verb changes to a nominal, e.g., from di to dilk̀, by adding the nominalizing suffix $-l \grave{\varepsilon}$. For a serial verb, only the second verb form is repeated. Compare the unemphasized (a) cases below with the (b) cases in which the verb is emphasized.:

(23)
a. ว̀ đì nàní
[ ò dì nàní ]
'he/she eats beef'

b. nàní dílè jè ò dí á ó

[ nànní dílè jè ò dí aa ó ]

'he/she eats only beef'

(24) a. ̀̀ dî

[ ò dî ]

'he/she eats (it)'

b. dílè jè ò dí á ó

[ đílè jè dí ấ ó ]

'he/she only

keeps eating'

(25)
a. ว̀ kù̀nì mì
[ ò kù̀nì mì ]
'he/she killed me'

b. kuńlè jè ò kù̀nì mì á ó

[ kứlè jè ò kùnì̀ mì á ó ]

'he/she only killed me'

Comparing the underlying forms in the (b) examples above with the realizations in phonetic brackets to their right, we see the effects of topic position on tone. For example, in (23), the underlying high tone of the verb in dilì is realized with Super-High as dîlè. Furthermore, Low Spreading is blocked in this position.

Some other languages of this group emphasize verbs in a similar way. In Eotilé, the emphasized verb appears in topic position in nominalized form, followed by the topic marker $c \mathcal{\varepsilon}$ and the full sentence, including the verb. Another emphasis marker $\grave{\varepsilon}$ is added to the right. In the example below, àbá is the nominalization of $b a ̀$ 'come.'

(26) a. wó bà lè

3sg come-Past'

'he/she has come' b. àbá ḉ wó bà lè ̀̀

Prefix-come-Rel-3sg-come-Past Emph.

'he/she has (actually) come' 


\section{Register Raising}

In Baule, the gradual raising of High tones for upsweep discussed in section 1.2 is distinct from the Super-High tone of emphasis. Tones that undergo upsweep are raised even higher for emphasis. And indeed we have noted that the two effects can occur together: Super-High tones in sequence exhibit upsweep. Thus, in (4), repeated here, both of the High tones of boli, when emphasized in (4b), are higher than the corresponding tones in (4a), and the second syllable of the emphasized word is higher than the first.
(4) a. / ákíssí bólí / [ ákísí bólí ] 'Akissi Boli' (proper name)
b. / ákíssí| bólí / [ ákísí bólî] 'Akissi Boli'

This is different from the situation in Hausa, as described by Inkelas and Leben (1990), where emphasizing a tone that is already Super-High does not raise this tone any higher. The fact that emphatic raising applies in this way leads us to suggest that emphasis creates a new, raised, tonal register. This view is supported by the fact that emphatic raising applies not just to High tones but also to Low tones. This is informally illustrated by the F0 pitch track below in figure 3 . Here the all-Low tone utterance, gbà̀flè̃ gbògbò kèklè 'the solid bread basket of the young man,' is spoken first normally, then emphatically. As one can see, there is an overall falling pitch contour in both cases. However, there is a difference in register: the emphatic sentence is realized with higher tones.

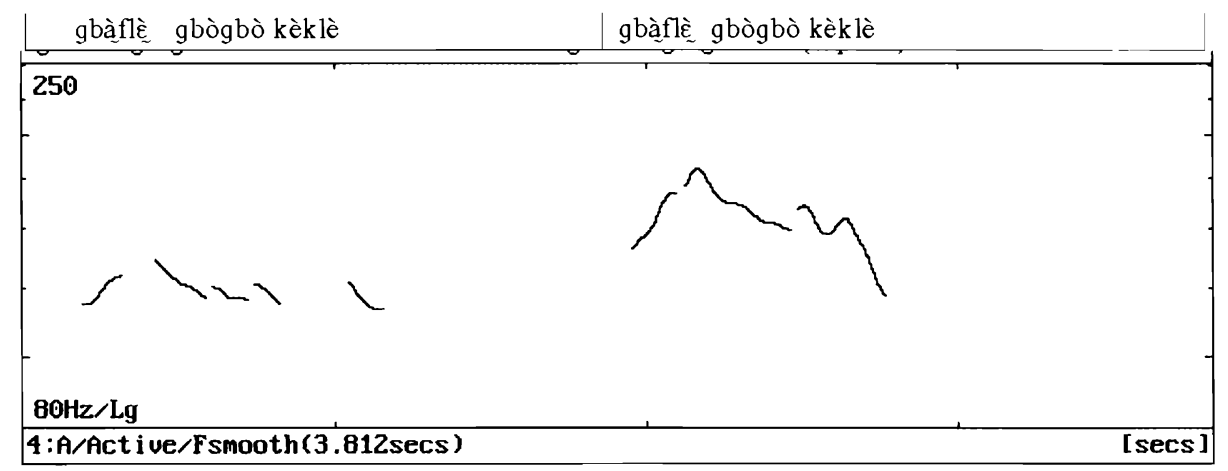

Figure 3: Normal vs. emphatic intonation. 
The same holds true for upsweep. As can be seen in Figure 4, the upsweep observed on the left in the non-emphatic version of the utterance be boli ní blú (every syllable bearing a High tone) 'the goats, their ten mothers' is preserved but at a raised level, in the emphatic version on the right.

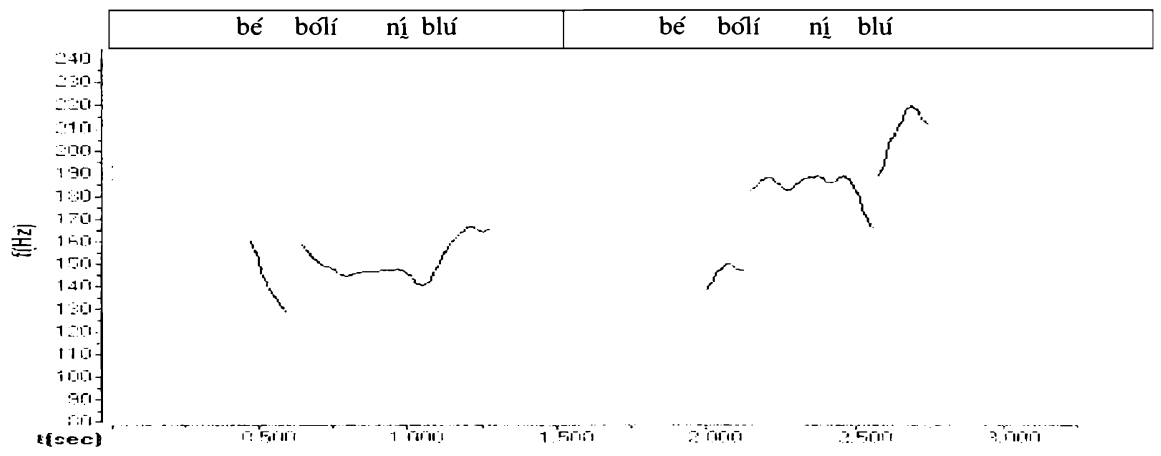

Figure 4: Upsweep in normal and in emphatic intonation.

A final sign that emphasis uses a new, raised register is that syllables following an emphasized word in the same phrase also must have their tone raised.

\section{Conclusion}

In this paper we have surveyed emphasis marking in several Kwa languages, collecting phonological reflexes of emphasis that go beyond the emphatic particles and raised intonations that are most frequently cited. Among the devices that signal or accompany emphasis are new boundary formation, blocking of phonological rules, and neutralization of phonological or semantic contrasts. We have also seen some signs of interactions with sequence structures, in which a non-emphasized tone in the same phrase will be raised to the same register level as the emphasized tone itself. Finally, this paper has shown that the raising of the register for emphasis co-exists with other intonational phenomena including downdrift and upsweep. 


\section{REFERENCES}

Ahoua, Firmin. 1996. Prosodic Aspects of Baule. Cologne: Rüdiger Köppe. Ameka, Felix. 1992. "Focus constructions in Ewe and Akan: A comparative perspective." In Proceedings of the the Kwa Comparative Syntax Workshop, ed. by Chris Collins and Victor Manfredi, pp. 1-25. Cambridge, MA: MIT.

Bearth, Thomas. 1999. "The contribution of African linguistics towards a general theory of focus." Journal of African Languages and Linguistics 11: 21-35.

Creissels, Dénis, and N. Jérémie Kouadio. 1979. Les tons du Baoulé. Abidjan: Institut de Linguistique Appliquée. Volume LXXV.

Inkelas, Sharon, and William. R. Leben. 1990. "Where phonology and phonetics intersect: The case of Hausa intonation." In Proceedings of the First Conference on Laboratory Phonology, ed. by Mary Beckman and John Kingston, pp. 17-34. Cambridge: Cambridge University Press.

Leben, William R., and Firmin Ahoua. 1997. "Prosodic domains in Baule." Phonology 14: 113-22.

. 2002. Contes et textes documentaires kwa de Côte d'Ivoire. Cologne:

Rüdiger Köppe.

Pierrehumbert, Janet B., and Mary E. Beckman. 1988. Japanese Tone Structure. Linguistic Inquiry Monograph.

Quaireau, A. 1981. Les Règles Tonales de l'Agni et du Baoulé. Doctoral thesis, Université de Nancy II.

Stewart, John M. 1989. "Kwa." In The Niger-Congo Languages, ed. by J. T. Bendor-Samuel, pp. 216-45. Lanham, MD: University Press of America.

. 2001. "Reclassifying the 'New Kwa' languages: The languages to the west of Tano (Akanoid)." Paper presented at the Thirty-First Colloquium on African Languages and Linguistics, University of Leiden.

. 2002. "Reconstruction of the Proto-Niger-Congo sound system: A progress report." Paper presented at the Thirty-Second Colloquium on African Languages and Linguistics, University of Leiden.

William R. Leben

Stanford University

email: leben@stanford.edu
Firmin Ahoua

Université de Cocody

email: fahoua2003@yahoo.fr 